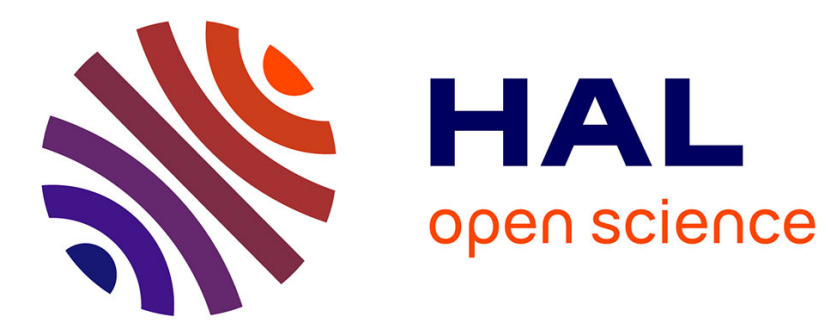

\title{
Simultaneous veneers incising and lower pressing temperatures-the effect on the plywood pressing time
}

\author{
A. Kurowska, P. Borysiuk, M. Ł. Mamiński
}

\section{To cite this version:}

A. Kurowska, P. Borysiuk, M. Ł. Mamiński. Simultaneous veneers incising and lower pressing temperatures-the effect on the plywood pressing time. European Journal of Wood and Wood Products, 2010, 69 (3), pp.495-497. 10.1007/s00107-010-0460-8 . hal-00615328

\section{HAL Id: hal-00615328 \\ https://hal.science/hal-00615328}

Submitted on 19 Aug 2011

HAL is a multi-disciplinary open access archive for the deposit and dissemination of scientific research documents, whether they are published or not. The documents may come from teaching and research institutions in France or abroad, or from public or private research centers.
L'archive ouverte pluridisciplinaire HAL, est destinée au dépôt et à la diffusion de documents scientifiques de niveau recherche, publiés ou non, émanant des établissements d'enseignement et de recherche français ou étrangers, des laboratoires publics ou privés. 
EJWWP460_source

Simultaneous veneers incising and lower pressing temperatures

- the effect on the plywood pressing time
A. KUROWSKA ${ }^{\mathrm{a}}(\bowtie)$, P. BORYSIUK ${ }^{\mathrm{a}}$, M.Ł. MAMIŃSKI ${ }^{\mathrm{a}}$
${ }^{a}$ Warsaw University of Life Sciences - SGGW, Faculty of Wood Technology, ul. Nowoursynowska 159, 02-776 Warsaw, Poland
Email: agnieszka_kurowska@sggw.pl 
EJWWP460_source

\begin{abstract}
It was shown that incising of veneers $\left(60-15 \mathrm{~m} / \mathrm{m}^{2}\right)$ prior to plywood bonding allowed reduction of pressing time by $8-9 \%$ for a pressing temperature of $90^{\circ} \mathrm{C}$ when compared to the controls. Nevertheless, with pressing temperatures lower than normal and shortened pressing times the shear strengths of the plywood met the requirements of the respective standards.
\end{abstract}

\title{
1 Introduction
}

For plywood, total pressing time is determined by the time necessary to achieve the sufficient temperature in the most internal glueline (stack core). Chow and Steiner (1975) stated that gelling of a urea-formaldehyde resin was initiated at $75^{\circ} \mathrm{C}$. Curing at the lowest possible and technologically acceptable temperature of $90-105^{\circ} \mathrm{C}$ improves dimensional stability of the plywood (Baldwin 1995). During pressing at temperatures above $100^{\circ} \mathrm{C}$, the steam generated in the system may disintegrate the glueline when the press is being opened too fast. Thus, it seems that simultaneous veneer incising and lower pressing temperatures result in reduced pressing times.

Veneer incising - also called “wood tenderizing” (O'Brien 1972, Hasegawa 1980, Masaru et al. 1984, Walser and Clarke 1991) - has been known for decades. Initially, it was realized prior to drying and was aimed at shortening the drying time, improving wood susceptibility to machining as well as - in case of veneers uniforming their strength parameters avoiding plywood twist and delamination (Walser and Clarke 1991).

The studies by Troughton and Lum (2000) showed that veneer incising followed by steam injection provided reduction of pressing time by $27 \%$ for $21-\mathrm{mm}$ thick 
EJWWP460_source

7-ply plywood and by $32 \%$ for $40-\mathrm{mm}$ thick 13 -ply LVL when compared to standard technology. On the other hand, Dai et al. (2003) stated that veneer incisions in 13-ply LVL manufacturing did not significantly affect pressing times nor mechanical performance of the product.

\section{Materials and methods}

Rotary-cut pine (Pinus sylvestris) veneers of dimensions $350 \times 350 \times 1.4 \mathrm{~mm}^{3}$ and $4 \%$ moisture content were used. $15-\mathrm{mm}$ long incisions were made along the fibers on the tight face of a veneer. Five series of 15-ply $20-\mathrm{mm}$ plywood with various incisions length $\left(60,45,30,15,10 \mathrm{~m} / \mathrm{m}^{2}\right)$ were prepared. In order to avoid glue leaks, the face veneers were non-incised. The control plywood was made of nonincised veneers. Glue rate was $160 \mathrm{~g} / \mathrm{m}^{2}$ (UF 100 parts, wheat flour 16 parts, $10 \%$ - solution of ammonium nitrate 3.5 parts, water 23 parts), pressing pressure 1.2 $\mathrm{N} / \mathrm{mm}^{2}$ and platens temperature $130 \pm 2^{\circ} \mathrm{C}$. The manufactured plywood was conditioned at $20 \pm 2^{\circ} \mathrm{C}, 65 \pm 5 \% \mathrm{RH}$ for 7 days.

Total pressing time $\left(\mathrm{t}_{\mathrm{p}}\right)$ was calculated from Equation (1):

$$
t_{p}=t_{g}+t_{o}
$$

where: $t_{g}$ - gelling time at a given temperature, $t_{o}$ - time of heating the most internal glueline (stack core) to a given temperature. Three temperatures were examined: $80^{\circ} \mathrm{C}, 90^{\circ} \mathrm{C}, 100^{\circ} \mathrm{C}$.

For the plywood prepared at the shortest pressing time, the shear strength of the gluelines and wood failure percentage were determined according to EN 314-1 and EN 314-2. Twenty specimens were tested in each batch. 
EJWWP460_source

\section{Results and discussion}

Gelling times $\left(\mathrm{t}_{\mathrm{g}}\right)$ of the glue at $80^{\circ} \mathrm{C}, 90^{\circ} \mathrm{C}$ and $100^{\circ} \mathrm{C}$ were 315,186 and $80 \mathrm{~s}$, respectively. Times of heating the most internal glueline to a given temperature $\left(\mathrm{t}_{\mathrm{o}}\right)$ and total pressing times are shown in Table 1.

\section{Table 1}

From the data presented in Table 1, it is clear that incising of veneers ranging from 15 to $60 \mathrm{~m} / \mathrm{m}^{2}$ allows reduction of total pressing time by $4-7 \%$ at $80^{\circ} \mathrm{C}, 8$ $9 \%$ at $90^{\circ} \mathrm{C}$ and $11-13 \%$ at $100^{\circ} \mathrm{C}$ when compared to controls.

Series with incisions length of $10 \mathrm{~m} / \mathrm{m}^{2}$ exhibited no significant alternation in heat transfer dynamics.

As the data in Table 1 indicate, the shortest pressing times were determined for $90^{\circ} \mathrm{C}$. Moreover, from Table 2 it is obvious that veneer incising does not significantly affect the dry shear strength of the resultant plywood. On the contrary to the dry strength, it occurred that the wet strengths were strongly affected by the incision length and the lowest values were observed for the plywood bearing $60 \mathrm{~m} / \mathrm{m}^{2}$. The incised plywood exhibited increased wood failure percentage when compared to the control, which can be explained by the weakened cohesion of the veneers and subsequently higher susceptibility to fracture propagation. However, it must be stressed that all the series studied met the requirements of EN 314.

\section{Table 2}


EJWWP460_source

\section{References}

Baldwin RF (1995) Plywood and veneer - based products: manufacturing practices. Miller Freeman Books, San Francisco

Dai C, Troughton GE, Wang B (2003) Development of a new incising technology for plywood/LVL production. Part 2. Effect of incising on LVL strength properties. Forest Prod J 53 (11/12): 99-102

Chow S, Steiner PR (1975) Catalytic exothermic reactions of urea-formaldehyde resin. Holzforschung 29 (1): 4-10

EN 314-1 (2007) Plywood - Bonding quality - Part 1: Test methods

EN 314-2 (2001) Plywood - Bonding quality - Part 2: Requirements

Hasegawa K (1980) Method of and apparatus for tenderizing veneer. U.S. Pat. No. $4,219,060$

Masaru K, Hasegawa Y, Shimosaka S, Aoyama N, Yoshizumi T (1984) Method and apparatus for drying veneer sheet. U.S. Pat. No. 4,486,963

O'Brian J C (1972) Veneer tenderizing apparatus. U.S. Pat. No. 3,678,974

Troughton GE, Lum C (2000) Pilot plant evaluation of steam - injection pressing for LVL and plywood products. Forest Prod J 50 (1): 25-28

Walser D, Clarke MR (1991) Wood tenderizing apparatus and method. Canadian Patent No. 1,292,925. 28 pp. 
EJWWP460_source

Table 1. Pressing conditions and reduction of pressing time

Tabelle 1 Pressbedingungen und Verkürzung der Pressdauer

Table 2. Shear strengths of the plywood pressed at $90^{\circ} \mathrm{C}$ (values in parentheses are standard deviations)

Tabelle 2 Scherfestigkeit von bei $90{ }^{\circ} \mathrm{C}$ gepresstem Sperrholz (Werte in Klammern sind Standardabweichungen)

Table 1

\begin{tabular}{|c|c|c|c|c|c|c|c|}
\hline $\begin{array}{l}\text { Temperature } \\
\text { in the stack } \\
\text { core }\end{array}$ & $\begin{array}{l}\text { Series } \\
\text { of the } \\
\text { plywood }\end{array}$ & $\begin{array}{l}\text { Incision } \\
\text { length }\end{array}$ & $\begin{array}{l}\text { Gelling } \\
\text { time } \\
\left(\mathrm{t}_{\mathrm{g}}\right)\end{array}$ & $\begin{array}{l}\text { Time of } \\
\text { heating the } \\
\text { most } \\
\text { internal } \\
\text { glueline } \\
\left(\mathrm{t}_{\mathrm{o}}\right)\end{array}$ & $\begin{array}{l}\text { Reducion } \\
\text { of } t_{o}\end{array}$ & $\begin{array}{c}\text { Total } \\
\text { pressing } \\
\text { time } \\
\left(\mathrm{t}_{\mathrm{g}}+\mathrm{t}_{\mathrm{o}}\right)\end{array}$ & $\begin{array}{l}\text { Reduction } \\
\text { of total } \\
\text { pressing } \\
\text { time }\end{array}$ \\
\hline${ }^{\circ} \mathrm{C}$ & & $\mathrm{m} / \mathrm{m}^{2}$ & $\mathrm{~s}$ & $\mathrm{~s}$ & $\%$ & $\mathrm{~s}$ & $\%$ \\
\hline \multirow[t]{6}{*}{80} & control & - & 315 & 402 & 0 & 717 & 0 \\
\hline & incised & 65 & 315 & 362 & 10 & 677 & 6 \\
\hline & & 45 & 315 & 365 & 9 & 680 & 5 \\
\hline & & 30 & 315 & 355 & 12 & 670 & 7 \\
\hline & & 15 & 315 & 372 & 7 & 687 & 4 \\
\hline & & 10 & 315 & 387 & 4 & 702 & 2 \\
\hline \multirow[t]{6}{*}{90} & control & - & 186 & 494 & 0 & 680 & 0 \\
\hline & incised & 65 & 186 & 433 & 12 & 619 & 9 \\
\hline & & 45 & 186 & 437 & 12 & 623 & 8 \\
\hline & & 30 & 186 & 431 & 13 & 617 & 9 \\
\hline & & 15 & 186 & 443 & 10 & 629 & 8 \\
\hline & & 10 & 186 & 466 & 6 & 652 & 4 \\
\hline \multirow[t]{6}{*}{100} & control & - & 80 & 656 & 0 & 736 & 0 \\
\hline & incised & 65 & 80 & 564 & 14 & 644 & 13 \\
\hline & & 45 & 80 & 568 & 13 & 648 & 12 \\
\hline & & 30 & 80 & 577 & 12 & 657 & 11 \\
\hline & & 15 & 80 & 578 & 12 & 658 & 11 \\
\hline & & 10 & 80 & 636 & 3 & 716 & 3 \\
\hline
\end{tabular}


EJWWP460_source

Table 2.

\begin{tabular}{ccccccc}
\hline $\begin{array}{c}\text { Series } \\
\text { of the } \\
\text { plywood }\end{array}$ & $\begin{array}{c}\text { Incision } \\
\text { length }\end{array}$ & $\begin{array}{c}\text { No. of } \\
\text { glueline }\end{array}$ & $\begin{array}{c}\text { Dry shear } \\
\text { strength }\end{array}$ & $\begin{array}{c}\text { Wood } \\
\text { failure }\end{array}$ & $\begin{array}{c}\text { Wet shear } \\
\text { strength }\end{array}$ & $\begin{array}{c}\text { Wood } \\
\text { failure }\end{array}$ \\
\hline control & $\mathrm{m} / \mathrm{m}^{2}$ & & $\mathrm{~N} / \mathrm{mm}^{2}$ & $\%$ & $\mathrm{~N} / \mathrm{mm}^{2}$ & $\%$ \\
& - & 1 & $3.44(0.27)$ & 60 & $2.73(0.18)$ & 40 \\
incised & 65 & 7 & $3.59(0.50)$ & 70 & $2.81(0.30)$ & 50 \\
& & 1 & $2.82(0.24)$ & 90 & $1.97(0.19)$ & 30 \\
& 45 & 1 & $2.67(0.40)$ & 70 & $1.90(0.19)$ & 50 \\
& 30 & 1 & $3.43(0.30)$ & 80 & $2.51(0.24)$ & 30 \\
& 15 & 1 & $3.26(0.26)$ & 90 & $2.10(0.22)$ & 50 \\
& 10 & 1 & $3.35(0.23)$ & 90 & $2.27(0.22)$ & 50 \\
& 10 & $3.34(0.31)$ & 90 & $2.37(0.26)$ & 50 \\
\hline
\end{tabular}

